\title{
Emissions of organic compounds from produced water ponds I: Characteristics and speciation
}

\author{
Seth N. Lyman ${ }^{\mathrm{a}, \mathrm{b}, *}$, Marc L. Mansfield ${ }^{\mathrm{a}, \mathrm{b}}$, Huy N.Q. Tran ${ }^{\mathrm{a}}$, Jordan D. Evans ${ }^{\mathrm{a}}$, Colleen Jones ${ }^{\mathrm{a}, \mathrm{c}}$, Trevor O'Neil ${ }^{\mathrm{a}}$, \\ Ric Bowers ${ }^{\mathrm{d}}$, Ann Smith ${ }^{\mathrm{d}}$, Cara Keslar $^{\mathrm{e}}$ \\ a Bingham Research Center, Utah State University, 320 N Aggie Blvd., Vernal, UT, USA \\ b Department of Chemistry and Biochemistry, Utah State University, 4820 Old Main Hill, Logan, UT, USA \\ c Department of Plants, Soils and Climate, Utah State University, 4820 Old Main Hill, Logan, UT, USA \\ d GSI Environmental, Inc., 9600 Great Hills Trail, Suite 350E, Austin, TX, USA \\ e Wyoming Department of Environmental Quality, 200 West 17th St., Cheyenne, WY, USA
}

\section{H I G H L I G H T S}

- Produced water ponds are a significant source of organics to the atmosphere.

- Prior to this work, emissions from produced water had not been adequately characterized.

- Produced water ponds are a significant source of hydrocarbons and alcohols.

- Methanol and C6-C9 alkanes and aromatics dominate fluxes from produced water ponds.

\section{G R A P H I C A L A B S T R A C T}

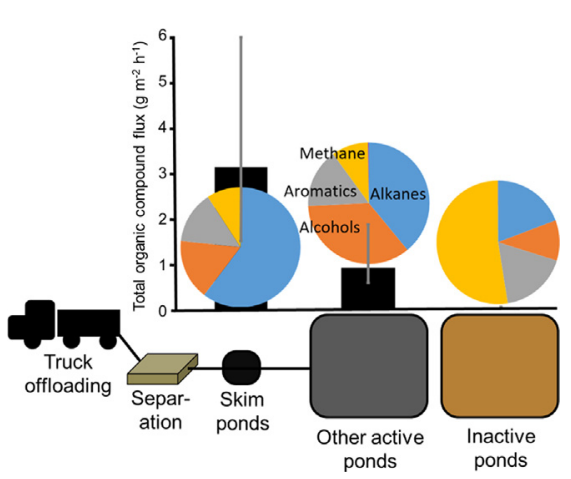

\begin{abstract}
A B S T R A C T
We measured fluxes of methane, a suite of non-methane hydrocarbons (C2-C11), light alcohols, and carbon dioxide from oil and gas produced water storage and disposal ponds in Utah (Uinta Basin) and Wyoming (Upper Green River Basin) United States during 2013-2016. In this paper, we discuss the characteristics of produced water composition and air-water fluxes, with a focus on flux chamber measurements. In companion papers, we will (1) report on inverse modeling methods used to estimate emissions from produced water ponds, including comparisons with flux chamber measurements, and (2) discuss the development of mass transfer coefficients to estimate emissions and place emissions from produced water ponds in the context of all regional oil and gasrelated emissions.

Alcohols (made up mostly of methanol) were the most abundant organic compound group in produced water (91\% of total volatile organic concentration, with upper and lower 95\% confidence levels of 89 and 93\%) but accounted for only $34 \%$ ( 28 to $41 \%$ ) of total organic compound fluxes from produced water ponds. Nonmethane hydrocarbons, which are much less water-soluble than methanol and less abundant in produced water, accounted for the majority of emitted organics. C6-C9 alkanes and aromatics dominated hydrocarbon fluxes, perhaps because lighter hydrocarbons had already volatilized from produced water prior to its arrival in storage or disposal ponds, while heavier hydrocarbons are less water soluble and less volatile. Fluxes of formaldehyde and other carbonyls were low ( $1 \%$ ( 1 to $2 \%$ ) of total organic compound flux). The speciation and
\end{abstract}

\footnotetext{
* Corresponding author at: Bingham Research Center, Utah State University, 320 N Aggie Blvd., Vernal, UT, USA.

E-mail address: seth.lyman@usu.edu (S.N. Lyman).
} 
magnitude of fluxes varied strongly across the facilities measured and with the amount of time water had been exposed to the atmosphere. The presence or absence of ice also impacted fluxes.

(C) 2017 Elsevier B.V. All rights reserved.

\section{Introduction}

Emissions to the atmosphere from the oil and gas industry include the greenhouse gases methane and carbon dioxide (Brandt et al., 2014; Howarth et al., 2011; Karion et al., 2013), as well as a suite of volatile organic compounds (VOC) and nitrogen oxides $\left(\mathrm{NO}_{\mathrm{x}}\right)$ (Edwards et al., 2014; Lyman and Tran, 2015; McDuffie et al., 2016; Prenni et al., 2016; Rappenglück et al., 2014), which can react in the atmosphere to form ozone and particulate pollution. Emissions from the oil and gas sector and their impacts on air quality and climate have been studied extensively (Allen et al., 2013; Brandt et al., 2014; Colborn et al., 2014; Hendler et al., 2009; Howarth et al., 2011; Karion et al., 2013; Warneke et al., 2014), and regional (Ahmadov et al., 2015; Bar-Ilan et al., 2006) and national (Maasakkers et al., 2016) inventories exist. In many cases, however, emissions inventories underestimate emissions measured using top-down approaches that capture emissions from entire fields or basins (Ahmadov et al., 2015; Brandt et al., 2014; Karion et al., 2013). This discrepancy could be due to underestimates in the emission factors or activity data used to generate emissions inventories. It could also be due to emission sources that are excluded from current emissions inventories.

Produced water storage and disposal ponds are not included in the Western Regional Air Partnership (WRAP) oil and gas emissions inventories for the western United States (Friesen et al., 2009), which have been used in the U.S. Environmental Protection Agency National Emissions Inventory (NEI) and a number of other official and unofficial inventory efforts. Authors of oil and gas emissions inventories have cited a lack of survey responses about produced water ponds, or expected low emissions, as reasons for excluding them (Bar-Ilan et al., 2006; Friesen et al., 2009).

Almost no studies of emissions from produced water ponds have been conducted. Field et al. (2015) measured the composition of an emission plume that was influenced by a produced water disposal facility. They found high concentrations of toluene and xylenes, though the measurements they collected were off-site and could have been influenced by other sources. Thoma (2009) measured organic compound emissions from two produced water disposal facilities in Colorado over a few days. More complete emissions data from produced water ponds are needed so this source category can be included in emissions inventories and adequately accounted for in air emissions regulations.

Produced water represents a large portion of the material brought to the surface during the oil and gas extraction process. More than 5 barrels of water are produced per barrel of oil in the United States, and 182 barrels of water are produced per Mmcf of natural gas (Clark and Veil, 2009). Most produced water in the United States is injected back into the subsurface, but about $2 \%$ is disposed of in surface ponds, which allow it to evaporate into the atmosphere (Clark and Veil, 2009). In the arid western United States, the percentage of produced water disposed of by evaporation is higher. In the Uinta Basin (in northeastern Utah; location of the majority of the measurements collected for this study), 11\% (about 11 million barrels annually) is disposed of this way (Chidsey, 2015). Water is also often stored in open ponds prior to subsurface injection.

Produced water is a complex solution containing hydrocarbons and other organic and inorganic compounds (Benko and Drewes, 2008; Clark and Veil, 2009; Dórea et al., 2007; Lu et al., 2006; Neff et al., 2011; Tibbetts et al., 1992; Utvik, 1999). Because constituents of produced water vary by region, well location, treatment methods and well depth, no absolute compositional definition exists for produced water (Veil et al., 2004). Total dissolved solids (TDS) in produced water range in concentrations from near zero to more than $75,000 \mathrm{ppm}$ (average of 13,200 for the Uinta Basin), and inorganic ions tend to be dominated by $\mathrm{Na}-\mathrm{Cl}$ (Zhang et al., 2009). Produced water tends to be rich in hydrocarbons, especially aromatics (Dórea et al., 2007; Field et al., 2015) and can contain high concentrations of water-soluble organics like methanol (Veil et al., 2004). Water from gas production tends to contain more light aromatics, including benzene, toluene, ethylbenzene, and xylene, than water from oil production (Benko and Drewes, 2008). Water disposed of or stored in open ponds often includes both produced water and fluid that flows back from the well to the surface after hydraulic fracturing (i.e., flow-back water).

Here we report on fluxes of a suite of organic compounds and carbon dioxide from produced water ponds at eight produced water disposal facilities in the Uinta Basin of Utah and the Upper Green River Basin of Wyoming during 2013-2016. This paper focuses on produced water composition and on the speciation, magnitude, and variability of fluxes from produced water to the atmosphere, using flux chamber measurements. Companion papers will discuss (1) methods and results from inverse modeling estimates of emissions from produced water ponds, including comparisons with flux chamber results (Tran et al., 2017), and (2) analysis of mass-transfer coefficients for compounds in produced water and development of facility-level and basin-level emission estimates (Mansfield et al., 2017). This study included measurements from ponds only and did not consider emissions from tank storage, transport, or processing of produced water.

\section{Experimental}

\subsection{Study locations}

The produced water disposal facilities sampled for this study were located in the Uinta Basin, Utah, and the Upper Green River Basin, Wyoming, in the United States. While the majority of produced water is injected into the subsurface without spending time in open ponds, the facilities sampled in this study all employed ponds, either for storage of water prior to injection or for evaporative disposal. Access was granted to some of the facilities on condition of anonymity, so facility names and other identifying information are not disclosed. Table S1 provides information about the number and types of measurements that occurred at each facility.

The produced water disposal facilities sampled in this study functioned as follows: (1) Produced water was separated from hydrocarbon liquids and natural gas by gravity and collected in a storage tank at an oil or gas well site. In some cases, water was piped directly to the disposal facility, rather than being stored in a tank. (2) Produced water was trucked or piped to a disposal facility, where it was released into a closed tank or vessel for additional gravity-based separation of water from oil. Some facilities employed more sophisticated techniques to separate water from oil (e.g., centrifugal separation), while some did not use any closed-tank separation. Water in well-site storage tanks was usually heated during cooler seasons, so water was usually warm when it arrived at disposal facilities (sometimes exceeding $40{ }^{\circ} \mathrm{C}$ ). (3) Water was transferred from separation tanks into open ponds. Ponds varied from less than 0.1 to several hectares in size. (4) Once in a pond, water was often transferred to additional ponds. Facilities we studied had from two to ten individual ponds. Most facilities utilized a small netted pond (often called a skim pond) downstream from the separation tank to catch additional residual oil before transfer to larger evaporation or storage ponds. (5) For some facilities, water was injected into the subsurface after storage in open ponds. For others, water 
remained at the surface to evaporate. In at least one case, a portion of the water was further treated and then discharged or reused in the oil and gas industry.

During some winter measurement campaigns, much of the water surface at disposal facilities was frozen. Some ponds, however, were so saline that despite sub-freezing air temperatures the water remained unfrozen. Also, since produced water was heated prior to disposal during winter months, areas of ponds that regularly received new water did not freeze or developed a layer of ice at night that thawed during the day.

We measured fluxes from a variety of surfaces at produced water disposal facilities, including skim ponds, other ponds with water that was recently received from well sites, ponds with aged, briny water, ice, fresh water ponds (i.e., water from fresh sources, not produced water), and a pond that had been reclaimed by covering with dirt and revegetation.

We used National Agriculture Imagery Program (NAIP) imagery in ArcGIS 10 to delineate ponds and calculate the acreage of each produced water pond at facilities we studied, as well as all produced water facilities in the Uinta Basin.

\subsection{Meteorological measurements}

We measured temperature and relative humidity (Campbell CS215 or New Mountain NM150WX), wind speed and direction (Gill WindSonic or New Mountain NM150WX), barometric pressure (Campbell CS100 or New Mountain NM150WX), and total incoming solar radiation (Campbell CS300) at each facility at $6 \mathrm{~m}$ above ground level and recorded these with a Campbell Scientific CR1000 data logger. To characterize atmospheric stability for many of the plume characterization/ inverse modeling measurements, we measured the change in temperature with height using aspirated temperature probes (Apogee TS-110) at 1 and $6 \mathrm{~m}$ above ground.

\subsection{Flux chamber}

We measured fluxes of carbon dioxide, methane, non-methane hydrocarbons (for a list of compounds measured, see U.S. Environmental Protection Agency (EPA) Document No. EPA/600-R-98/161 (EPA, 1998)), and light alcohols (methanol, ethanol, and isopropanol) using a modified version of the commonly-used (Hafner et al., 2010; Leduc et al., 2009; Lyman et al., 2017; Wang et al., 2011) dynamic EPA Emission Isolation Flux Chamber (Eklund, 1992). Dynamic flux chambers work by flowing air through a chamber that covers a portion of the surface to be measured. If a compound of interest is being emitted from the surface, the concentration of that compound will increase in the chamber relative to the outside air (or decrease if the gas of interest is depositing). The flux of the compound to or from the surface can be calculated as

$\mathrm{F}=(\Delta \mathrm{C} \times \mathrm{FR}) / \mathrm{S}$,

where $\mathrm{F}$ is the water-air flux in $\mathrm{mg} \mathrm{m}^{-2} \mathrm{~h}^{-1}, \Delta \mathrm{C}$ is the difference in concentrations of the compound of interest inside versus outside the chamber in $\mathrm{mg} \mathrm{m}^{-3}$, FR is the flow rate in $\mathrm{m}^{3} \mathrm{~h}^{-1}$, and $\mathrm{S}$ is the surface area covered by the chamber in $\mathrm{m}^{2}$ (Denmead, 2008). A diagram of our measurement system is given in Fig. S1.

While flux chambers have been widely used for flux measurements from water and other surfaces, including fluxes of greenhouse gases (Denmead, 2008; Kasimir-Klemedtsson et al., 1997), methanol (de Gouw et al., 1999) and various hydrocarbons (Boudries et al., 2002; Gallego et al., 2014), they are known to suffer from biases. Turbulence inside flux chambers is constant, so effects of wind speed on fluxes may not be fully accounted for by chamber methods (Denmead, 2008) (this is discussed in a companion paper (Mansfield et al., 2017)). Chamber flow rates and the presence or absence of mixing fans can alter measured fluxes (Parker et al., 2013). Also, chambers can alter temperatures of the surface being studied and the air above it, especially if they are transparent, as our chamber was (see Supplemental information).

In spite of these limitations, chambers are the only surface flux measurement method that can be used in any meteorological or topographical condition, or among any number of adjacent sources (Denmead, 2008; Göckede et al., 2004). Produced water disposal facilities typically contain many ponds and non-pond emission sources, so isolating a single source or differentiating among sources is difficult with the plume characterization/inverse modeling family of methods, and adequately incorporating complex terrain and structures in plume characterization models can be difficult (Theobald et al., 2012). Also, produced water ponds usually have berms that are well above the water level, making it difficult to achieve the large, uniform fetch required for micrometeorological methods (Twine et al., 2000). Neither of these methods works well in conditions with low and meandering wind (Marchant et al., 2011; Twine et al., 2000), which are common during winter in the study areas (Lyman and Tran, 2015). Thus, we used a dynamic flux chamber for most of our measurements, and we periodically conducted plume characterization/inverse modeling measurements to compare against the flux chamber measurements. Plume characterization/inverse modeling measurements are reported in a companion paper (Tran et al., 2017).

The chamber employed in this study was an acrylic hemispherical dome with a diameter of $41 \mathrm{~cm}$. A polystyrene foam sheet with dimensions of $3 \mathrm{~cm} \times 122 \mathrm{~cm} \times 122 \mathrm{~cm}$ with a hole cut from the center for the chamber provided for floatation, and strings attached to the chamber anchored it in place. The chamber had a fan at the top with a polyethylene blade that turned at about 100 rotations per minute to achieve a uniform concentration of measured compounds within the chamber (as in Pape et al., 2009). We tested the impact of fan speed on measured fluxes by comparing measured fluxes from produced water at the same location while the fan was rotating fast enough to agitate the water within the chamber and at the normal speed $(\mathrm{n}=3$ for high speed, $\mathrm{n}=4$ for normal speed). Fluxes were significantly higher for ethane and propane (1.8, and 1.5 times higher, respectively) with the fan rotating at high speed, but were not significantly different for any of the other measured compounds.

A $1.2 \mathrm{~cm}$ hole on one side allowed ambient air to enter the chamber. Air was pulled through the chamber via a $1 \mathrm{~cm} \times 45 \mathrm{~m}$ PFA line connected to the opposite side of the chamber, continually supplying the chamber with ambient air. Air outside the chamber was sampled via a $1 \mathrm{~cm}$ diameter $\times 45 \mathrm{~m}$ PFA line near the $1.2 \mathrm{~cm}$ hole. Total flow through each line was 10 standard $\mathrm{L} \mathrm{min}{ }^{-1}$ (standard conditions of $1 \mathrm{~atm}$ and $21{ }^{\circ} \mathrm{C}$ ). Flow through the outside line was regulated with a rotameter (the rotameter was positioned downstream of analytical instrumentation), and flow through the inside line was regulated with an Alicat MC stainless steel mass flow controller. $47 \mathrm{~mm}$ in-line PTFE filters with $0.5 \mu \mathrm{m}$ pore size were installed at the beginning of sample lines to prevent particle contamination of sample air. Concentrations of measured compounds were converted from ppm to $\mathrm{mg} \mathrm{m}^{-3}$ using standard conditions of $1 \mathrm{~atm}$ and $21^{\circ} \mathrm{C}$.

The $45 \mathrm{~m}$ PFA lines both connected to solenoid valves and then to a laser-based methane and carbon dioxide analyzer (LGR Ultraportable Greenhouse Gas Analyzer), which switched between the lines every $2 \mathrm{~min}$. PFA tees also connected the inside and outside lines to $6 \mathrm{~L}$ stainless steel air sampling canisters. During 2013 and 2014, SUMMA canisters were used. During 2015 and 2016, canisters coated with deactivated fused silica were used. Flow into the canisters was regulated with Alicat MC stainless steel mass flow controllers. Canisters were collected over 30-60 min, and flows were regulated at 55-125 standard $\mathrm{mL} \mathrm{min}^{-1}$. All mass flow controllers used in this study were checked annually with BIOS DryCal flow meters that were calibrated annually against a NIST-traceable standard and were always within $\pm 5 \%$ of the expected value. 


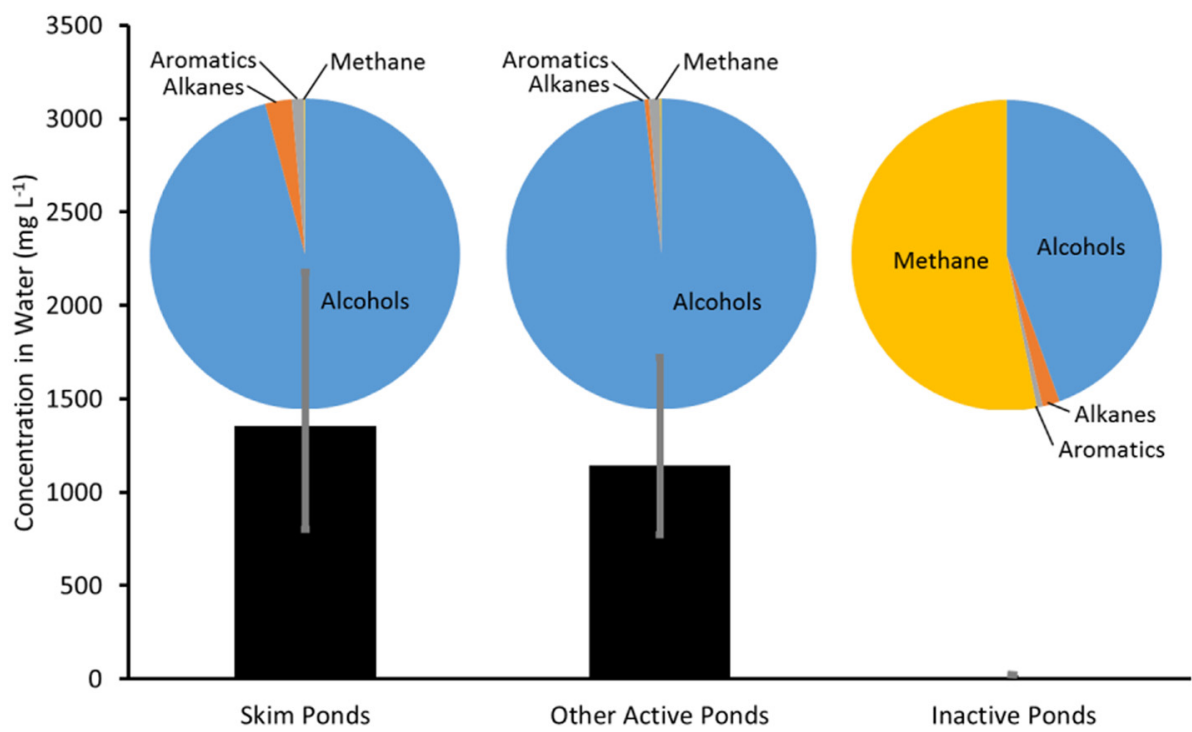

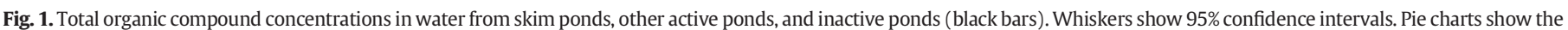
fraction of total concentrations that were due to alcohols, alkanes, aromatics, and methane.

A Campbell CR1000 data logger recorded flows, meteorological data, thermocouple temperatures, and the LGR analyzer output at $20 \mathrm{~s}$ intervals. We washed the chamber, tubing and wires, and foam floatation device periodically with soap and water and then rinsed them in methanol and flushed the system with air overnight to remove oil and grease. We measured fluxes periodically from a clean, $1 / 8^{\prime \prime}$ thick PTFE surface (including before and after cleaning) to assess system contamination.

We checked the LGR analyzer daily against a National Institute of Standards and Technology (NIST)-traceable standard at two calibration points ( 0 and $30 \mathrm{ppm}$ for methane, 0 and $5610 \mathrm{ppm}$ for carbon dioxide) and periodically, including after instrument repairs and maintenance, at four calibration points $(0,6,30$, and $1000 \mathrm{ppm}$ for methane, 0,570 , 1120 , and $5610 \mathrm{ppm}$ for carbon dioxide). Calibration checks in scrubbed air $(n=67)$ resulted in 15 (upper and lower $95 \%$ confidence intervals of 8 and 34$) \mathrm{ppb}$ for methane and $1.0(0.8,1.3) \mathrm{ppm}$ for carbon dioxide.
Calibration checks from compressed gas standards $(\mathrm{n}=86)$ resulted in $99(99,100) \%$ recovery for methane (90th and 10th percentiles of $101 \%$ and $97 \%$, respectively) and $100(99,101) \%$ recovery for carbon dioxide (90th and 10th percentiles of 104\% and 96\%). Methane concentrations inside the chamber occasionally approached $1000 \mathrm{ppm}$, and methane calibrations at $1000 \mathrm{ppm}(\mathrm{n}=14)$ resulted in only 93 (91, 96 )\% recovery since $1000 \mathrm{ppm}$ is slightly outside the linear range of the LGR analyzer. Using 3 times the standard deviation of the instrument response when subjected to scrubbed air, the detection limits were $3 \mathrm{ppb}$ for methane and $1.4 \mathrm{ppm}$ for carbon dioxide. Additional information about methane and carbon dioxide measurements is available in the supporting information.

After sampling, canisters were analyzed within 30 days. In 2013 and 2014, SUMMA canisters were analyzed for hydrocarbons by GC-FID according to EPA PAMS analysis protocols (EPA, 1998), and alcohols were

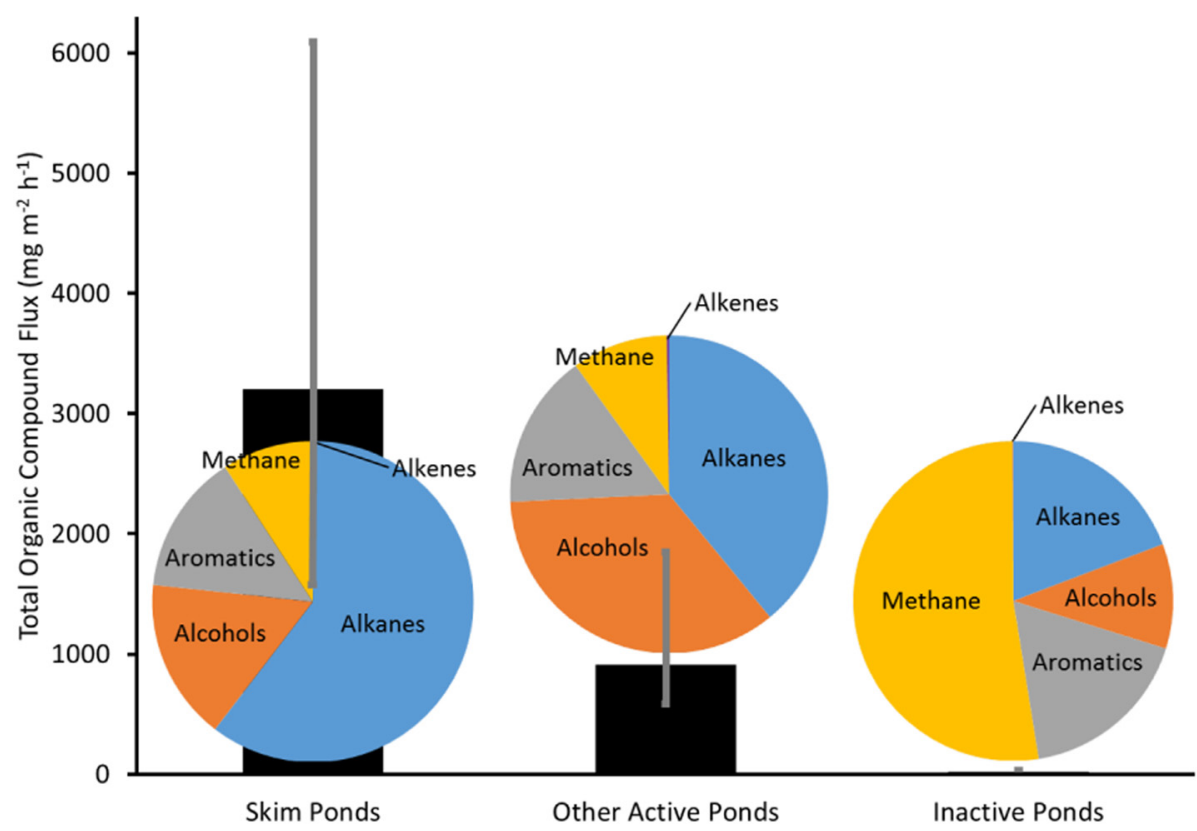

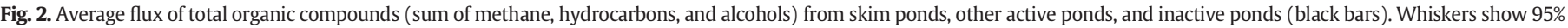

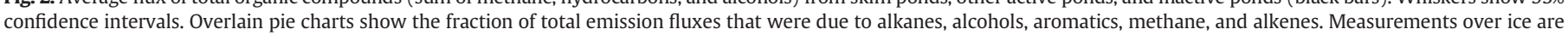
excluded. 
Table 1

Fluxes of organic compounds from skim ponds, other active ponds, and inactive ponds. Measurements over ice are excluded.

\begin{tabular}{|c|c|c|c|}
\hline $\mathrm{mg} \mathrm{m}^{-2} \mathrm{~h}^{-1}$ & Skim ponds & Other active ponds & Inactive ponds \\
\hline Methane & $367.5(164.9,786.0)$ & $90.5(68.1,124.3)$ & $14.2(7.8,25.5)$ \\
\hline Carbon dioxide & $495.9(311.7,881.2)$ & $433.6(365.5,530.7)$ & $544.6(425.1,695.3)$ \\
\hline Alkanes & $2425.1(900.3,5064.6)$ & $361.7(114.2,1502.9)$ & $5.2(1.2,20.3)$ \\
\hline Alkenes & $1.4(0.7,2.9)$ & $2.0(0.5,6.2)$ & $0(0,0)$ \\
\hline Aromatics & $567.4(259.6,1085.6)$ & $145.9(89.7,242.5)$ & $4.8(1.8,11.4)$ \\
\hline Alcohols & $652.6(249.7,1202.4)$ & $326.0(166.1,711.2)$ & $2.9(1.6,5.5)$ \\
\hline Total non-methane organics & $3646.5(1410.2,7355.5)$ & $835.7(370.5,2462.8)$ & $12.9(4.6,37.2)$ \\
\hline
\end{tabular}

analyzed according to EPA TO-15 protocols (EPA, 1999) by a commercial laboratory (AAC, Ventura, California). In 2015 and 2016, silonitecoated canisters were analyzed in our laboratory. We used an Entech 7200 preconcentrator and 7016D autosampler to concentrate samples and introduce them to a gas chromatograph (GC) system for analysis. We used cold trap dehydration to reduce water vapor in the sample, as described by Wang and Austin (2006). The GC system consisted of two Shimadzu GC-2010 GCs with a flame ionization detector (FID) and a Shimadzu QP2010 Mass Spectrometer (MS), respectively. Additional information about methods for canister sample processing and analysis is available in the Supporting Information.

Detection limits for the compounds analyzed by GC were 1.1 $(0.9,1.3) \mathrm{ppb}$ (calculated as 3 times the standard deviation of repeated analyses of a calibration sample with concentrations near the detection limit), with no significant trend with elution order (Student's t-test; $\mathrm{p}=0.16$ ). The detection limits for alcohols were not significantly different from those for hydrocarbons $(\mathrm{p}=$ 0.12 ).

We calculated flux detection limits using twice the method detection limits for methane, carbon dioxide, and individual non-methane organic compounds as $\Delta C$, resulting in values of $0.02,22.71$ and $0.05(0.04$, $0.06) \mathrm{mg} \mathrm{m}^{-2} \mathrm{~h}^{-1}$, respectively. When the flux chamber was operated on a PTFE sheet, fluxes for methane, carbon dioxide, total hydrocarbons, and total alcohols were $0.02(-0.01,0.04), 16.5(-31,109), 0.24$ $(-0.14,0.72)$, and $0.11(0.06,0.14) \mathrm{mg} \mathrm{m}^{-2} \mathrm{~h}^{-1}$, respectively $(\mathrm{n}=$ 8 ). Fluxes for individual hydrocarbons and alcohols from the PTFE sheet were $0.006(0.002,0.012) \mathrm{mg} \mathrm{m}^{-2} \mathrm{~h}^{-1}$.

To verify that compounds emitted into the chamber could be quantitatively recovered by the measurement system, and as a practical estimate of the uncertainty in flux measurements, we filled a small pool (1.5 m diameter) with tap water to a depth of about $0.2 \mathrm{~m}$ and placed the flux chamber in the water. We injected undiluted gas from the same compressed gas standards used for calibration into the center of the chamber via a PFA tube that extended $1 \mathrm{~cm}$ above the water level. During these tests and during many of the flux chamber sampling periods, condensation was present on the inside of the chamber. We injected methane, carbon dioxide, hydrocarbon, and alcohol calibration gases at $200 \mathrm{~mL} \mathrm{~min}^{-1}$ at concentrations of $1620,152,000,1$, and 43 ppm, respectively (balance nitrogen). Recovery was $101(99,104) \%$ for methane $(n=5), 103 \%$ for carbon dioxide $(n=2), 104$ (101, $107) \%$ for hydrocarbons, and $48(44,51) \%$ for alcohols $(n=5$ for hydrocarbons and alcohols).

We expect that the low recovery for alcohols was due to dissolution of emitted alcohols into the water, so we repeated the test for alcohols by injecting alcohols and methane into the chamber while the chamber rested on a $3 \mathrm{~mm}$ thick PTFE sheet. We induced condensation in the chamber by adding humidified air to the inside of the chamber and covering the outside of the chamber with ice. When the chamber was operated this way, but no calibration gas was added, alcohol and methane fluxes were not significantly different from zero $(n=3$, $p$ values from t-test ranged from 0.24 to 0.96 ). When calibration gas was added and condensation existed in the chamber $(n=2)$, methane recovery was $93 \%$ and alcohol recovery was $78 \%$. When no condensation existed $(n=1)$ recovery of methane was $94 \%$ and recovery of alcohols was $95 \%$. We were unable to correct for this apparent bias since we did not consistently record whether condensation was present in the chamber during field sampling.

For a subset of measurements, we collected carbonyls on DNPH cartridges (Sigma-Aldrich P/N 54278-U) with the flux chamber and analyzed them with a Hewlett Packard 1050 HPLC with a Restek Ultra AQ C18 column and a diode array detector, following the method of Uchiyama et al. (2009). Additional information about this analysis can be found in the Supplemental Information. The flux detection limits for individual carbonyls were between 0.01 and $0.02 \mathrm{mg} \mathrm{m}^{-2} \mathrm{~h}^{-1}$. Injections of a solution containing formaldehyde and propionaldehyde into the inside chamber line $(\mathrm{n}=5)$ resulted in $80(70,93) \%$ and 88 $(79,92) \%$ recovery, respectively.

\subsection{Water analysis}

We collected water samples from ponds at each facility we visited. We collected these samples with a $500 \mathrm{~mL}$ polyethylene jar attached to a $3 \mathrm{~m}$ pole. All samples were collected $3 \mathrm{~m}$ or less from the edge of ponds. Water was transferred from the jar into $40 \mathrm{~mL}$ amber vials with septum lids without headspace.

In 2013, samples collected in $40 \mathrm{~mL}$ vials were analyzed for methane by method RSK-175 (Kampbell and Vandegrift, 1998), for methanol by EPA Method 8015B (EPA, 1996a) by ALS Environmental in Fort Collins, Colorado, and for other organics by EPA Method 8260B (EPA, 1996b) by American West Analytical Laboratories in Salt Lake City, Utah. After

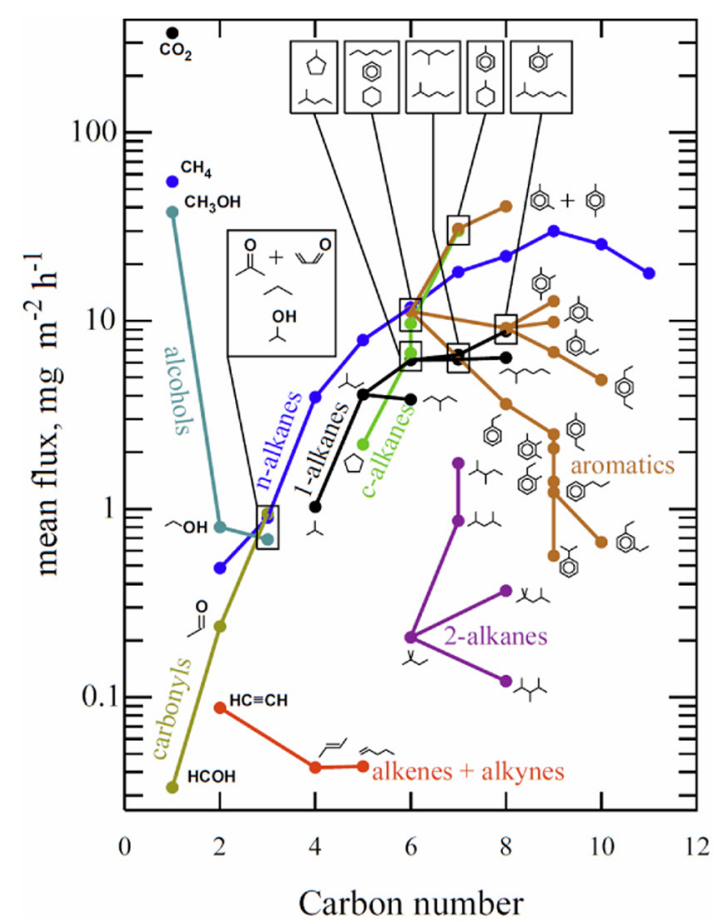

Fig. 3. Hydrocarbon speciation signature of fluxes from produced water ponds. Coloration is by compound class. Compound classes are connected by straight lines as a guide to the eye. 
2013, we analyzed water samples for the same organic compounds for which we analyzed air canister samples, except that we did not analyze water samples for alkenes, undecane, or isopropyl benzene, and we did analyze water samples for methane. Water samples were analyzed using the same GC/MS system that was used to analyze air samples, with the same configuration and columns. $0.8 \mathrm{~g} \mathrm{NaCl}$ was added to $20 \mathrm{~mL}$ septum-top autosampler vials, and then $10 \mathrm{~mL}$ of sample was transferred from the $40 \mathrm{~mL}$ amber sample vial into the autosampler vials. Samples were then analyzed via headspace analysis with a PAL COMBI-xt autosampler. Each sample was heated to $60{ }^{\circ} \mathrm{C}$ and agitated

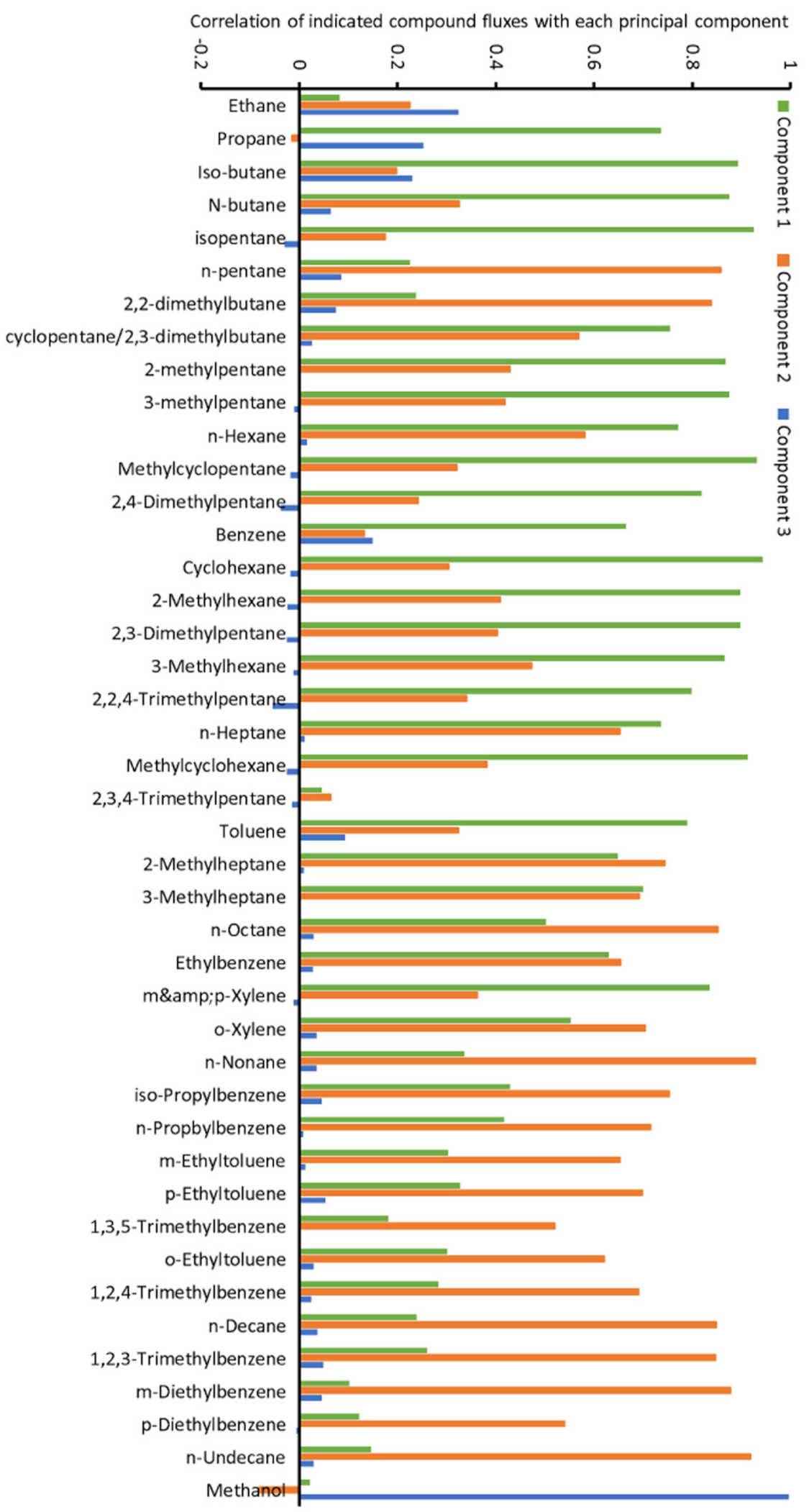

Fig. 4. Correlation of indicated organic compound fluxes with each of three components identified in a principal component analysis. 
for $10 \mathrm{~min}$, then $1 \mathrm{~mL}$ of headspace was extracted from the vial with a syringe heated to $100{ }^{\circ} \mathrm{C}$ and injected into a split injection port on the GC.

Additional information about methods for determination of organic compounds in water, as well as other water analysis methods used, is available in the Supporting information.

\subsection{Statistical analysis}

Except where otherwise indicated, $\mathrm{r}^{2}$ values shown are for Pearson correlations. Comparisons of two datasets were conducted using student's $t$-tests. Statistical significance was determined at $\alpha=0.05$. We calculated bootstrapped $95 \%$ confidence intervals using the BCa method (DiCiccio and Efron, 1996). We present results as bootstrapped means with lower and upper confidence levels in parentheses.

We performed a principal components analysis of C2-C11 hydrocarbon and alcohol fluxes using SPSS Version 22 (Guo, 2011; Mishra et al., 2015; Swartzendruber et al., 2006). To minimize the complexity of the dataset, we excluded methane, carbon dioxide and alkene fluxes from the final analysis, but the results were similar when these compound fluxes were included. We analyzed a covariance matrix with varimax rotation and only retained the three components that had eigenvalues greater than the mean. The first component explained 59.5\% of the total variance, the second component explained $33.1 \%$, and the third component explained $4 \%$.

\section{Results and discussion}

\subsection{Produced water composition}

For convenience, we categorized ponds at produced water facilities as skim ponds, which were the first pond in a series, were usually netted, and were usually at least partially covered with oil (these are called skim ponds because oil is periodically skimmed from the ponds' surfaces); other active ponds, which were actively receiving new produced water but were not the first pond in a series, and inactive ponds, which had water in them but were not receiving new water. At the time of sampling, inactive ponds had not received new produced water for weeks to months, but the exact age of water in inactive ponds could not be determined.

Inactive ponds had higher total dissolved solids (TDS; 47.7 (34.5, 61.7) $\mathrm{g} \mathrm{L}^{-1}$ ) than skim ponds and other active ponds (15.9 (11.3,

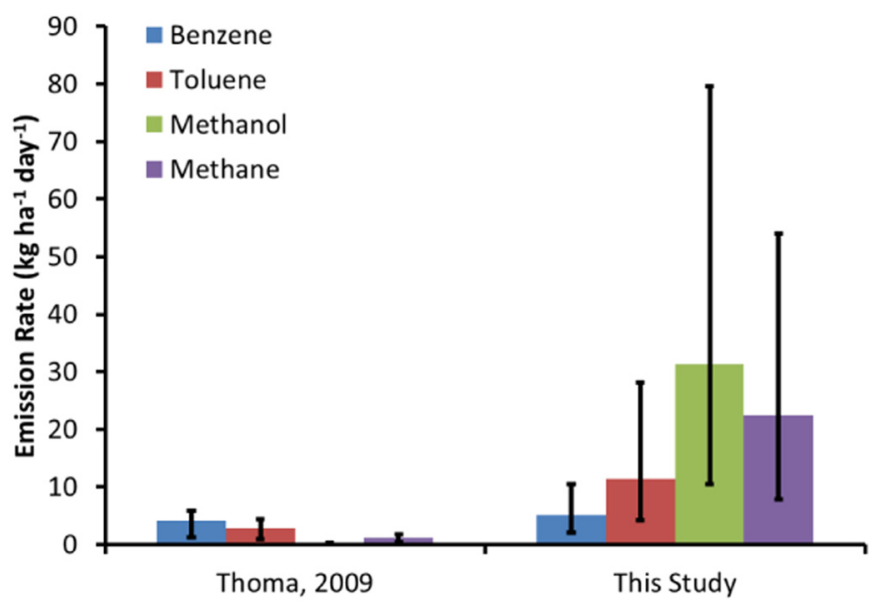

Fig. 6. Emissions of select organic compounds from three produced water disposal ponds (one skim pond and two other active ponds), as reported by Thoma (2009) compared with emissions from this study (average of all pond types at all facilities in the Uinta Basin). Whiskers show 95\% confidence intervals.

20.5) and $23.5(18.9,28.6) \mathrm{g} \mathrm{L}^{-1}$, respectively), probably because water in inactive ponds had experienced more evaporation. $\mathrm{pH}$ was similar for all three pond types $(8.1(7.8,8.3)$ for all pond types). Concentrations of organic compounds were highest and most variable in skim ponds, followed by other active ponds and inactive ponds (Fig. 1). For skim ponds and other active ponds, organics in water were dominated by alcohols. Alcohols accounted for $90(82,95) \%$ of all organics measured from these two pond types. For inactive ponds, in contrast, methane made up the largest fraction of organic compounds measured. At least some of this methane was likely produced by methanogenic bacteria (see discussion in next section).

Speciation of NMHC and alcohols did not vary dramatically among skim, other active, and inactive produced water ponds (Fig. S2). C6-C8 compounds made up the vast majority of NMHC observed in produced water. For the subset of water samples analyzed by a commercial laboratory using EPA method 8260B (EPA, 1996b), acetone $(2.4(1.9,2.9)$ $\left.\mathrm{mg} \mathrm{L}^{-1}\right)$, butyl acetate $\left(0.9(0.5,1.2) \mathrm{mg} \mathrm{L}^{-1}\right)$, n-butanol (16.5 (14.1, 18.4) $\left.\mathrm{mg} \mathrm{L}^{-1}\right)$, and naphthalene $\left(88.4(0.2,265.8) \mathrm{mg} \mathrm{L}^{-1}\right)$ were also consistently observed. Formaldehyde and acetaldehyde were also consistently observed $\left(0.8(0.3,1.7)\right.$ and $\left.0.1(0.1,0.1) \mathrm{mg} \mathrm{L}^{-1}\right)$, but
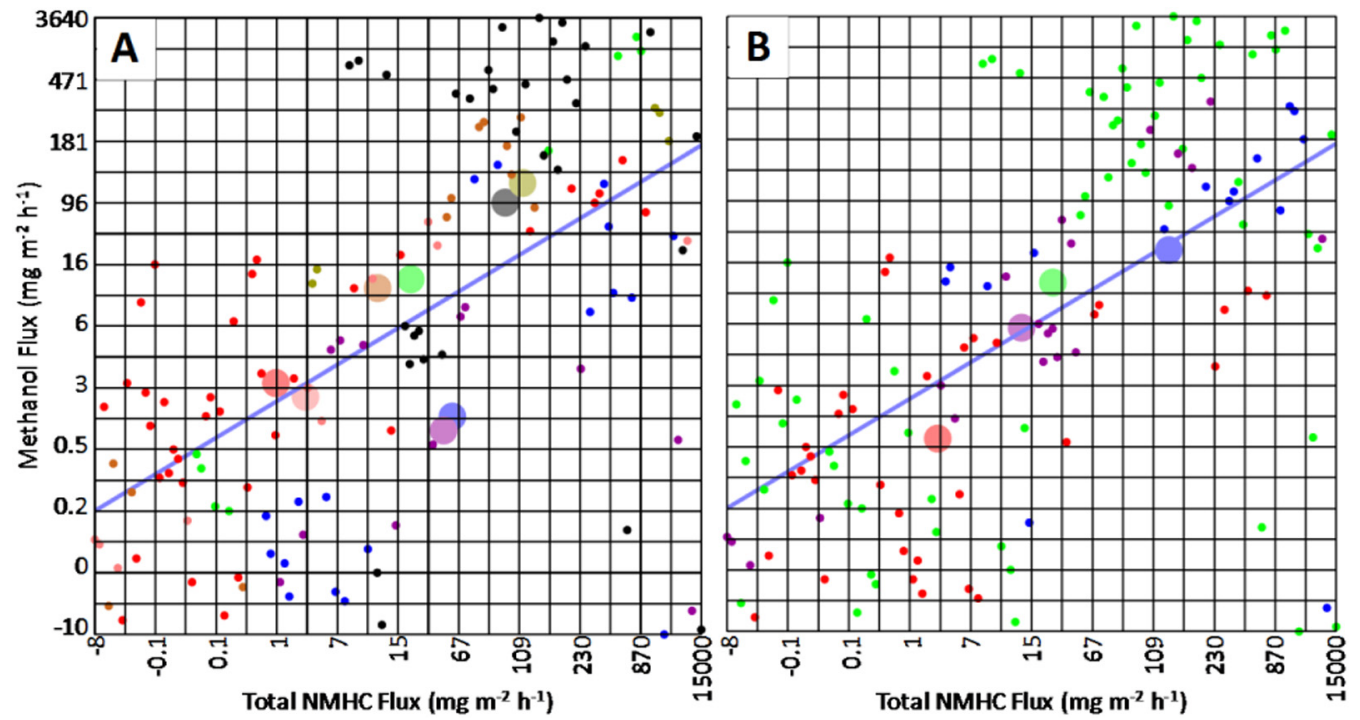

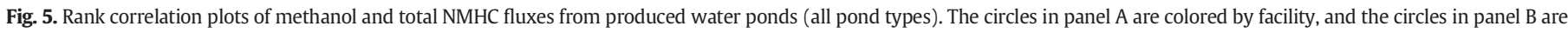

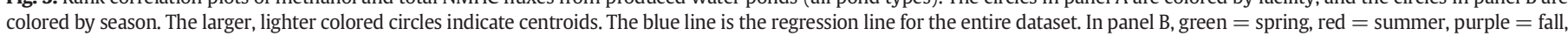
and blue $=$ winter. (For interpretation of the references to colour in this figure legend, the reader is referred to the web version of this article.) 
accounted for only $0.5(0.2,1.0) \%$ of organic compounds in produced water.

Methanol concentrations were much higher than those of any other measured non-methane organic compound in all pond types (Figs. 1 and S1). Methanol is used in the oil and gas industry to prevent methane hydrate formation and is typically either injected at well heads or added to raw gas transmission pipelines during winter. Methanol is also used year-round as a solvent in anti-scaling or other chemical treatment products injected into well bores or at other stages of oil and gas production. Methanol is miscible with water and can be expected to partition preferentially into the water phase during gravimetric separation of water from oil and gas. Methane, alkanes, and aromatics are much less soluble and so are less likely to remain in the water phase after separation. The source of ethanol and isopropanol in produced water is not clear, but it could be an impurity in methanol used by the oil and gas industry.

Benko and Drewes (2008) summarized available information about concentrations of organic compounds in produced water. They report concentrations of 0.39 to $35 \mathrm{mg} \mathrm{L}^{-1}$ of total volatile organics in produced water. In contrast, we measured total organics in the range of 0.6 to $1356 \mathrm{mg} \mathrm{L}^{-1}$, with an average of $760 \mathrm{mg} \mathrm{L}^{-1}$. The method used to obtain the values reported by Benko and Drewes, however, likely did not quantify light hydrocarbons or alcohols. When alcohols and C1-C5 hydrocarbons are excluded, our results ranged from 0 to $41.5 \mathrm{mg} \mathrm{L}^{-1}$, within the range Benko and Drewes reported.

\subsection{Fluxes from produced water ponds}

Fluxes of methane, carbon dioxide, non-methane hydrocarbons, and alcohols from produced water surface impoundments varied widely across and within facilities because of differences in the composition of water received at facilities, water management practices, meteorological conditions, and the interval of time over which a given body of water had been stored at the site. Fig. 2 shows that fluxes of organic compounds from skim ponds were much higher than fluxes from other active ponds and that the flux from inactive ponds was by far the lowest. Total organic compound fluxes from skim, other active, and inactive ponds were 3198.5 (1555.9, 6087.6), 907.1 (589.1, $1845.1)$, and $18.8(10.9,33.0) \mathrm{mg} \mathrm{m}^{-2} \mathrm{~h}^{-1}$, respectively. Fluxes of different compound groups from different pond types are shown in Table 1.

Fig. 2 shows that the speciation of organic compound fluxes was different for skim, other active, and inactive ponds. Fluxes from skim ponds tended to be dominated by alkanes, while alcohols and aromatics made up a larger portion of fluxes from other active ponds. This may have occurred because alkanes tend to be more volatile and less water soluble than alcohols and aromatics, so they can be expected to emit from skim ponds quickly, leaving fewer alkanes in solution to be emitted from downstream ponds. Fluxes of alkenes were very low, probably because alkenes are present at very low concentrations in petroleum in general (Tissot and Welte, 1984) (alkene concentrations were not measured in water).

Fluxes from skim ponds were the most variable (Fig. 2). One cause of this variability was that a portion of the surface of skim ponds was usually covered with oil, and some flux chamber measurements were collected from oil surfaces. Oil surfaces were also occasionally observed on other active ponds. For a subset of measurements that were collected from oil surfaces and nearby water surfaces, oil surfaces resulted in total non-methane hydrocarbon (NMHC), alcohol, and methane fluxes that were $32(13,49), 13(0,26)$, and $6(1,9)$ times higher, respectively, than nearby water surfaces.

While methane fluxes were greatest from skim ponds, followed by other active ponds, the percent of total organic compound flux that was due to methane was highest for inactive ponds, followed by other active ponds. It is likely that the dominant source of methane emitted from other active and inactive ponds was methanogenic bacteria, since much of the methane that was dissolved in produced water when it arrived at the disposal facility would be quickly volatilized, and since older water would have time to develop a larger bacterial population. The bacterial MPN value for skim ponds was $78(22,135)$, while the values for other active and inactive ponds were 242 (215, 275 ) and 267 (236, 303), respectively, providing evidence for this hypothesis. The carbon dioxide flux from skim ponds was not significantly different from all other ponds.

The speciation of NMHC and alcohol fluxes stayed roughly the same for skim ponds, other active ponds, and inactive ponds (Fig. S3). Fig. 3 displays the average speciation of NMHC fluxes from produced water ponds as a function of compound speciation and relative flux. The hydrocarbon signature was dominated by C6-C9 alkanes and aromatics. Fluxes of the lighter alkanes were relatively low. These probably have a higher concentration in produced water when it first comes out of the ground, but flash quickly in separators, tanks, or during transport and are less abundant by the time produced water reaches disposal or storage ponds. Alkane solubility in water decreases with increasing chain length (Eastcott et al., 1988), which, along with their lower volatility, explains why C10 and heavier alkanes made up a smaller fraction of total flux.

For the subset of measurements that included carbonyls $(n=56)$, carbonyls fluxes $\left(1.2(0.8,1.7) \mathrm{mg} \mathrm{m}^{-2} \mathrm{~h}^{-1}\right)$ accounted for $1(1,2) \%$ of total organic compound fluxes. Acrolein and acetone (eluted together during HPLC analysis) made up $76(65,85) \%$ of total carbonyl fluxes. Formaldehyde and acetaldehyde made up $4(1,10) \%$ and $15(9,24) \%$, respectively, and the other measured carbonyls made up the remaining $5 \%$.

We divided fluxes for each compound by the concentration of each compound in water and calculated correlations between the concentration-weighted fluxes and meteorological parameters measured, but none of the correlations were statistically significant. We expect that the extreme variability in water composition and fluxes masked the much smaller variability caused by changes to meteorological conditions. Longer-term measurements on a few ponds would be better able than our study design (short-term measurements on many ponds) to elucidate relationships between fluxes and meteorological conditions.

Ice cover lowered fluxes dramatically when it was present. For a subset of measurements of fluxes from active ponds that had some ice cover and some unfrozen water, the unfrozen portion had 174 times higher methane flux $(25.0(12.7,37.5)$ versus $0.1(0.0,0.3)$ $\left.\mathrm{mg} \mathrm{m}^{-2} \mathrm{~h}^{-1}\right), 131$ times higher total hydrocarbon flux (1200.6 $(575.6,1787.5)$ versus $\left.9.2(7.1,12.7) \mathrm{mg} \mathrm{m}^{-2} \mathrm{~h}^{-1}\right)$, and 12 times higher methanol flux $(167.7(102.8,237.1)$ versus $14.0(6.6,30.8)$ $\mathrm{mg} \mathrm{m}^{-2} \mathrm{~h}^{-1}$ ) than ice-covered surfaces. Fig. S4 shows an example of fluxes increasing as ice melts on a winter morning. Fluxes of organic compounds from water surfaces tended to be higher during winter than during other seasons (e.g., total organic compound flux of 1223.2 $(702.1,1764.3)$ versus $819(562.2,1251.6) \mathrm{mg} \mathrm{m}^{-2} \mathrm{~h}^{-1}$ for other active ponds).

We observed strong correlations among many NMHC fluxes, including both alkanes and aromatics (Figs. S5-S10). Correlations were stronger for compounds that were more closely related (e.g., $r^{2}$ for n-octane and n-nonane was 0.89 , while $r^{2}$ for ethylbenzene and propane was $0.13)$. Carbon dioxide and methane were poorly correlated with hydrocarbons and with each other (Figs. S9-S10; $\mathrm{r}^{2}$ for methane and total $\mathrm{NMHC}=0.19 ; \mathrm{r}^{2}$ for carbon dioxide and total NMHC was not significant). Fluxes of carbon dioxide and methane likely depend, at least partly, on the bacterial population in produced water, rather than just on the composition of water when it is received at a facility. Because of this, strong correlations should not be expected. Fig. 2 lends additional support to this finding.

Fluxes of alcohols (which were dominated by methanol; Fig. S3) were poorly correlated with hydrocarbon fluxes (e.g., no significant correlation between methanol and total NMHC). A principal component 
analysis (Guo, 2011; Mishra et al., 2015; Swartzendruber et al., 2006) resulted in three main components to explain the observed variability in hydrocarbon and methanol fluxes (Fig. 4). The first component was dominated by $\mathrm{C} 3-\mathrm{C} 8$ hydrocarbons, the second by $\mathrm{C} 8-\mathrm{C} 11$ hydrocarbons, and the third by methanol (with little hydrocarbon influence), indicating that methanol and hydrocarbon fluxes may not have originated from the same source. Alcohols do not naturally exist in significant concentrations in oil or natural gas (Tissot et al., 1978), and we expect that the amount of alcohols added during oil and gas production varies by operator, formation, and season. Fig. 5 shows a rank correlation of NMHC and methanol fluxes, colored by facility and season.

We also measured fluxes from a produced water pond that had been reclaimed by covering it with soil and re-vegetating it. Fluxes from the reclaimed pond were not significantly different from fluxes measured from a PTFE sheet.

\subsection{Comparison with previous work}

The only other published measurements of emissions of organic compounds from produced water ponds are those of Thoma (2009). Thoma measured emissions from produced water ponds in Colorado during August 2008 using two open-path Fourier transform infrared spectrometers, SUMMA canisters, and vertical radial plume mapping. Fig. 6 shows the average emission rate of a few select organic compounds from the three ponds measured by Thoma (which included one pond identified as a skim pond and two ponds identified as evaporation ponds), in comparison with our measurements. We averaged the results of the three ponds measured by Thoma in Fig. 6 and, to present data from the two studies in as similar a way as possible, we averaged the emissions we measured from all pond types at all facilities. This led to the high variability observable in Fig. 6, since skim ponds, active ponds, and inactive ponds had very different emission rates.

Emission rates of all compounds measured by Thoma were lower than those from this study, with the exception of benzene, which was similar in both studies. The reason for the difference between the two studies is not clear. The sample size in the Thoma study was small, and it is impossible to know whether its results are representative of emissions from produced water ponds in Colorado.

Our chamber measurements likely underestimated fluxes during periods with high winds, as examined in a companion paper (Mansfield et al., 2017). Correction for wind speed led to wholefacility emissions that were about 2.5 times higher than flux chamber data. Correction for wind speed affected emission speciation. Fig. S13 shows flux speciation for wind-corrected data.

\section{Acknowledgments}

This work was funded by the Research Partnership to Secure Energy for America/U.S. Department of Energy National Energy Technology Laboratory (Contract No. 12122-15), the State of Wyoming, the Uinta Impact Mitigation Special Service District, the Utah Legislature, and the Utah School and Institutional Trust Lands Administration. We are also grateful to the produced water disposal companies that allowed us to access the facilities sampled in this study.

\section{Appendix A. Supplementary data}

Supplementary data to this article can be found online at https://doi. org/10.1016/j.scitotenv.2017.11.161.

\section{References}

Ahmadov, R., McKeen, S., Trainer, M., Banta, R., Brewer, A., Brown, S., Edwards, P.M., de Gouw, J.A., Frost, G.J., Gilman, J., Helmig, D., Johnson, B., Karion, A., Koss, A., Langford, A., Lerner, B., Olson, J., Oltmans, S., Peischl, J., Petron, G., Pichugina, Y., Roberts, J.M., Ryerson, T., Schnell, R., Senff, C., Sweeney, C., Thompson, C., Veres, P.R., Warneke, C., Wild, R., Williams, E.J., Yuan, B., Zamora, R., 2015. Understanding high wintertime ozone pollution events in an oil- and natural gas-producing region of the western US. Atmos. Chem. Phys. 15, 411-429.

Allen, D.T., Torres, V.M., Thomas, J., Sullivan, D.W., Harrison, M., Hendler, A., Herndon, S.C. Kolb, C.E., Fraser, M.P., Hill, A.D., 2013. Measurements of methane emissions at natural gas production sites in the United States. Proc. Natl. Acad. Sci. U. S. A. 110, 17768-17773.

Bar-Ilan, A., Grant, J., Parikh, R., Morris, R., Sgamma, K., Moore, T., Gribovicz, L., 2006. A Comprehensive Emissions Inventory of Upstream Oil and Gas Activities in the Rocky Mountain States. ENVIRON International Corporation, Western Energy Alliance, Western Governors' Association Western Regional Air Partnership.

Benko, K.L., Drewes, J.E., 2008. Produced water in the Western United States: geographical distribution, occurrence, and composition. Environ. Eng. Sci. 25, 239-246.

Boudries, H., Bottenheim, J., Guimbaud, C., Grannas, A., Shepson, P., Houdier, S., Perrier, S. Domine, F., 2002. Distribution and trends of oxygenated hydrocarbons in the high Arctic derived from measurements in the atmospheric boundary layer and interstitial snow air during the ALERT2000 field campaign. Atmos. Environ. 36, 2573-2583.

Brandt, A., Heath, G., Kort, E., O'Sullivan, F., Pétron, G., Jordaan, S., Tans, P., Wilcox, J., Gopstein, A., Arent, D., 2014. Methane leaks from north American natural gas systems. Science 343, 733-735.

Chidsey, T., 2015. Basin-scale Produced Water Management Tools and Options-GIS-Based Models and Statistical Analysis of Shale Gas/tight Sand Reservoirs and Their Produced-Water Streams, Uintah Basin. Utah, Utah Geological Survey, Salt Lake City, Utah https://www.netl.doe.gov/file\%20library/research/oil-gas/11123-08-finalreport.pdf.

Clark, C., Veil, J., 2009. Produced water volumes and management practices in the United States. Argonne National Laboratory (ANL). http://www.ipd.anl.gov/anlpubs/2009/ 07/64622.pdf.

Colborn, T., Schultz, K., Herrick, L., Kwiatkowski, C., 2014. An exploratory study of air quality near natural gas operations. Hum. Ecol. Risk. Assess. 20, 86-105.

de Gouw, J.A., Howard, C.J., Custer, T.G., Fall, R., 1999. Emissions of volatile organic compounds from cut grass and clover are enhanced during the drying process. Geophys. Res. Lett. 26, 811-814.

Denmead, O., 2008. Approaches to measuring fluxes of methane and nitrous oxide between landscapes and the atmosphere. Plant Soil 309, 5-24.

DiCiccio, T.J., Efron, B., 1996. Bootstrap confidence intervals. Stat. Sci. 189-212.

Dórea, H.S., Bispo, J.R., Aragão, K.A., Cunha, B.B., Navickiene, S., Alves, J.P., Romão, L.P., Garcia, C.A., 2007. Analysis of BTEX, PAHs and metals in the oilfield produced water in the State of Sergipe, Brazil. Microchem. J. 85, 234-238.

Eastcott, L., Shiu, W.Y., Mackay, D., 1988. Environmentally relevant physical-chemical properties of hydrocarbons: a review of data and development of simple correlations. Oil Chem. Pollut. 4, 191-216.

Edwards, P.M., Brown, S.S., Roberts, J.M., Ahmadov, R., Banta, R.M., deGouw, J.A., Dube W.P., Field, R.A., Flynn, J.H., Gilman, J.B., Graus, M., Helmig, D., Koss, A., Langford, A.O., Lefer, B.L., Lerner, B.M., Li, R., Li, S.-M., McKeen, S.A., Murphy, S.M., Parrish, D.D., Senff, C.J., Soltis, J., Stutz, J., Sweeney, C., Thompson, C.R., Trainer, M.K., Tsai, C., Veres, P.R., Washenfelder, R.A., Warneke, C., Wild, R.J., Young, C.J., Yuan, B., Zamora, R., 2014. High winter ozone pollution from carbonyl photolysis in an oil and gas basin. Nature 514, 351-354.

Eklund, B., 1992. Practical guidance for flux chamber measurements of fugitive volatile organic emission rates. J. Air Waste Manage. Assoc. 42, 1583-1591.

EPA, U.S, 1996a. Method 8015B: Nonhalogenated Organics Using GC/FID. United States Environmental Protection Agency, Research Triangle Park, North Carolina http:// www.caslab.com/EPA-Methods/PDF/8015b.pdf.

EPA, U.S., 1996b. Method 8260B: Volatile Organic Compounds by Gas Chromatography/ Mass Spectrometry (GC/MS). United States Environmental Protection Agency http://www.epa.gov/wastes/hazard/testmethods/sw846/pdfs/8260b.pdf.

EPA, U.S., 1998. Technical Assistance Document for Sampling and Analysis of Ozone Precursors. United States Environmental Protection Agency, Research Triangle Park, North Carolina http://www.epa.gov/ttn/amtic/files/ambient/pams/newtad.pdf.

EPA, U.S., 1999. Compendium Method TO-15: Determination of Volatile Organic Compounds (VOCs) in Air Collected in Specially-Prepared Canisters and Analyzed by Gas Chromatography/Mass Spectrometry (GC/MS). United States Environmental Protection Agency, Cincinnati, Ohio http://www.epa.gov/ttn/amtic/files/ambient/airtox/ to-15r.pdf.

Field, R.A., Soltis, J., McCarthy, M.C. Murphy, S., Montague, D.C., 2015. Influence of oil and gas field operations on spatial and temporal distributions of atmospheric nonmethane hydrocarbons and their effect on ozone formation in winter. Atmos. Chem. Phys. 15, 3527-3542.

Friesen, R., Parikh, R. Grant, J., Bar-Ilan, A., Pollack, A., Henderer, D., Pring, D., Sgamma, K. Schlagel, P., 2009. Development of Baseline 2006 Emissions From Oil and Gas Activity in the Uinta Basin. Prepared for Western Regional Air Partnership.

Gallego, E., Perales, J., Roca, F., Guardino, X., 2014. Surface emission determination of volatile organic compounds (VOC) from a closed industrial waste landfill using a selfdesigned static flux chamber. Sci. Total Environ. 470, 587-599.

Göckede, M., Rebmann, C., Foken, T., 2004. A combination of quality assessment tools for eddy covariance measurements with footprint modelling for the characterisation of complex sites. Agric. For. Meteorol. 127, 175-188.

Guo, H., 2011. Source apportionment of volatile organic compounds in Hong Kong homes. Build. Environ. 46, 2280-2286.

Hafner, S.D., Montes, F., Rotz, C.A., Mitloehner, F., 2010. Ethanol emission from loose corn silage and exposed silage particles. Atmos. Environ. 44, 4172-4180.

Hendler, A., Nunn, J., Lundeen, J., 2009. VOC Emissions from Oil and Condensate Storage Tanks: Final Report Prepared for Texas Environmental Research Consortium. Texas Environmental Research Consortium http://www.mcilvainecompany.com/Decision Tree/subscriber/articles/Emissions_From_Oil_and_Condensate_Storage_Tanks_Final_ Report.pdf.

Howarth, R.W., Santoro, R., Ingraffea, A., 2011. Methane and the greenhouse-gas footprint of natural gas from shale formations. Clim. Chang. 106, 679-690.

Kampbell, D.H., Vandegrift, S.A., 1998. Analysis of dissolved methane, ethane, and ethylene in ground water by a standard gas chromatographic technique. J. Chromatogr Sci. 36, 253-256. 
Karion, A., Sweeney, C. Petron, G., Frost, G., Hardesty, R.M., Kofler, J., Miller, B.R Newberger, T., Wolter, S., Banta, R., Brewer, A., Dlugokencky, E., Lang, P., Montzka, S.A., Schnell, R., Tans, P., Trainer, M., Zamora, R., Conley, S., 2013. Methane emissions estimate from airborne measurements over a western United States natural gas field. Geophys. Res. Lett. 40, 4393-4397.

Kasimir-Klemedtsson, Å., Klemedtsson, L., Berglund, K., Martikainen, P., Silvola, J. Oenema, O., 1997. Greenhouse gas emissions from farmed organic soils: a review. Soil Use Manag. 13, 245-250.

Leduc, R., Fécil, B., Leconte, C., Normandin, Y., Pagé, T., 2009. Odour and VOC impact assessment and air quality monitoring program at a municipal solid waste landfill. Water Pract. Technol. 4, wpt2009032.

Lu, J., Wang, X., Shan, B., Li, X., Wang, W., 2006. Analysis of chemical compositions contributable to chemical oxygen demand (COD) of oilfield produced water Chemosphere 62, 322-331.

Lyman, S., Tran, T., 2015. Inversion structure and winter ozone distribution in the Uintah Basin, Utah, USA. Atmos. Environ. 123, 156-165.

Lyman, S.N., Watkins, C., Jones, C.P., Mansfield, M.L., McKinley, M., Kenney, D., Evans, J. 2017. Hydrocarbon and carbon dioxide fluxes from natural gas well pad soils and surrounding soils in Eastern Utah. Environ. Sci. Technol. 51, 11625-11633.

Maasakkers, J.D., Jacob, D.J., Sulprizio, M.P., Turner, A.J., Weitz, M., Wirth, T., Hight, C. DeFigueiredo, M., Desai, M., Schmeltz, R., 2016. Gridded national inventory of US methane emissions. Environ. Sci. Technol. 50, 13123-13133.

Mansfield, M.L., Tran, H.N.Q., Lyman, S.N., Smith, A., Bowers, R., 2017. Emissions of organic compounds from produced water ponds III: mass-transfer coefficients, compositionemission correlations, and contributions to regional emissions. Sci. Total Environ. (submitted).

Marchant, C., Moore, K., Wojcik, M., Martin, R., Pfeiffer, R., Prueger, J., Hatfield, J., 2011. Estimation of dairy particulate matter emission rates by lidar and inverse modeling. Trans. ASABE 54, 1453-1463.

McDuffie, E.E., Edwards, P.M., Gilman, J.B., Lerner, B.M., Dubé, W.P., Trainer, M., Wolfe, D.E., Angevine, W.M., deGouw, J., Williams, E.J., 2016. Influence of oil and gas emissions on summertime ozone in the Colorado Northern Front Range. J. Geophys. Res. Atmos. 121, 8712-8729.

Mishra, N., Bartsch, J., Ayoko, G.A., Salthammer, T., Morawska, L., 2015. Volatile organic compounds: characteristics, distribution and sources in urban schools. Atmos. Environ. 106, 485-491.

Neff, J., Lee, K., DeBlois, E.M., 2011. Produced Water: Overview of Composition, Fates, and Effects, Produced Water. Springer, pp. 3-54

Pape, L., Ammann, C., Nyfeler-Brunner, A., Spirig, C., Hens, K., Meixner, F., 2009. An automated dynamic chamber system for surface exchange measurement of non-reactive and reactive trace gases of grassland ecosystems. Biogeosciences 6, 405-429.

Parker, D., Ham, J., Woodbury, B. Cai, L, Spiehs, M., Rhoades, M., Trabue, S., Casey, K, Todd, R., Cole, A., 2013. Standardization of flux chamber and wind tunnel flux measurements for quantifying volatile organic compound and ammonia emissions from area sources at animal feeding operations. Atmos. Environ. 66, 72-83.

Prenni, A., Day, D., Evanoski-Cole, A., Sive, B., Hecobian, A., Zhou, Y., Gebhart, K., Hand, J. Sullivan, A. Li, Y, 2016. Oil and gas impacts on air quality in federal lands in the Bakken region: an overview of the Bakken air quality study and first results. Atmos. Chem. Phys. 16, 1401-1416.
Rappenglück, B., Ackermann, L., Alvarez, S., Golovko, J., Buhr, M., Field, R., Soltis, J., Montague, D.C. Hauze, B., Adamson, S., 2014. Strong wintertime ozone events in the Upper Green River basin, Wyoming. Atmos. Chem. Phys. 14, 4909-4934.

Swartzendruber, P.C., Jaffe, D.A., Prestbo, E.M., Weiss-Penzias, P., Selin, N.E., Park, R., Jacob, D.J., Strode, S., Jaeglé, L., 2006. Observations of reactive gaseous mercury in the free troposphere at the Mt. Bachelor Observatory. J. Geophys. Res. 111, D24301.

Theobald, M.R., Løfstrøm, P., Walker, J., Andersen, H.V., Pedersen, P., Vallejo, A., Sutton, M.A., 2012. An intercomparison of models used to simulate the short-range atmospheric dispersion of agricultural ammonia emissions. Environ. Model. Softw. 37, 90-102.

Thoma, E., 2009. Measurement of Emissions from Produced Water Ponds: Upstream Oil and Gas Study \#1. U.S. Environmental Protection Agency, Cincinnati, Ohio http:// nepis.epa.gov/Adobe/PDF/P100EACG.pdf.

Tibbetts, P.J.C., Buchanan, I.T., Gawel, L.J., Large, R., 1992. A comprehensive determination of produced water composition. In: Ray, J., Engelhardt, F.R. (Eds.), Produced Water. Springer, US, pp. 97-112.

Tissot, B.P., Welte, D.H., 1984. From Kerogen to petroleum, Petroleum Formation and Occurrence. Springer, pp. 160-198.

Tissot, B., Deroo, G., Hood, A., 1978. Geochemical study of the Uinta Basin: formation of petroleum from the Green River formation. Geochim. Cosmochim. Acta 42, 1469-1485.

Tran, H.N.Q., Lyman, S.N., Mansfield, M.L., O'Neil, T., 2017. Emissions of organic compounds from produced water ponds II: evaluation of flux-chamber measurements with inverse-modeling techniques. J. Air Waste Manage. Assoc. (submitted).

Twine, T.E., Kustas, W., Norman, J., Cook, D., Houser, P., Meyers, T., Prueger, J., Starks, P., Wesely, M., 2000. Correcting eddy-covariance flux underestimates over a grassland. Agric. For. Meteorol. 103, 279-300.

Uchiyama, S., Naito, S., Matsumoto, M., Inaba, Y., Kunugita, N., 2009. Improved measurement of ozone and carbonyls using a dual-bed sampling cartridge containing trans1,2-bis (2-pyridyl) ethylene and 2,4-dinitrophenylhydrazine-impregnated silica. Anal. Chem. 81, 6552-6557.

Utvik, T.I.R., 1999. Chemical characterisation of produced water from four offshore oil production platforms in the North Sea. Chemosphere 39, 2593-2606.

Veil, J.A., Puder, M.G., Elcock, D., Redweik Jr., R.J., 2004. A White Paper Describing Produced Water From Production of Crude Oil, Natural Gas, and Coal Bed Methane. Argonne National Laboratory, Technical Report.

Wang, D., Austin, C., 2006. Determination of complex mixtures of volatile organic compounds in ambient air: canister methodology. Anal Bioanal Chem. 386, 1099-1120.

Wang, T., Sattayatewa, C., Venkatesan, D., Noll, K.E., Pagilla, K.R., Moschandreas, D.J., 2011. Comparison of two dynamic measurement methods of odor and odorant emission rates from freshly dewatered biosolids. J. Environ. Monit. 13, 1746-1752.

Warneke, C. Geiger, F. Edwards, P.M., Dube, W Petron, G, Kofler, J Zahn, A. Brown, S.S, Graus, M., Gilman, J.B., Lerner, B.M., Peischl, J., Ryerson, T.B., de Gouw, J.A., Roberts, J.M., 2014. Volatile organic compound emissions from the oil and natural gas industry in the Uintah Basin, Utah: oil and gas well pad emissions compared to ambient air composition. Atmos. Chem. Phys. 14, 10977-10988.

Zhang, Y., Gable, C.W. Zyvoloski, G.A., Walter, L.M., 2009. Hydrogeochemistry and gas compositions of the Uinta Basin: a regional-scale overview. AAPG Bull. 93, 1087-1118. 